\title{
Recent articles:
}

Reform or Democratization for Africa?:

Troubling Constraints and Partial Solutions John F. Clark

South Africa: The Long and Arduous

Road to a New Dispensation

Margaret C. Lee

Africa and the Changing Global Arena

Charles O. Kwarteng

Southern African Development Community: Challenges Ahead

William A. Lindeke

Africa in the 21st Century: Confronting Cultural, Economic, and Technological

Diversity

Georges Nzongola-Ntalaja

Democratic Ethnic Conflict Management in Africa

Harvey Glickman

\section{Randall Robinson} PRESIDENT

TransAfrica Fourm: A Research and Educational Institute

\section{TRANSAFRICA FORUM}

\section{Published Quarterly}

\section{Subscription rates:}

Individuals: $\$ 32 / y r ; \$ 60 / 2 y r s ; \$ 80 / 3 y r s$ Institutions: $\$ 72 / y r ; \$ 128 / 2 y r s ; \$ 168 / 3 y r s$

Foreign surface mail add $\$ 32 / \mathrm{yr}$

Foreign airmail add $\$ 48 / \mathrm{yr}$

(Rates subject to change annually)

Visit us on the web at

Presents an

independent reaieze

of U.S. policy

tozuard Africa and

the Caribbean.

Offers information on political,

economic, and

cultural matters

affecting black

comminnities

globally, for a better

understanding of

policy issues and

their impact

zoorldzwide.

http://MWW.TRANSACTIONPUB.COM

$$
\text { Call 908/445-2280 or Fax 908/445-3138 }
$$


". . one of the most important journals of history in the world."

- Small Press

\section{The Journal of}

INTERDISCIPLINARY History

Edited by Robert I. Rotberg and Theodore K. Rabb

This distinguished scholarly publication incorporates the con-

"JIH has faithfully

maintained its

tradition of

innovation ...

exploring the

relation between

history and the

sociai sciences. In

this area it has

acquired a

considerable

reputation, which it

continues to

deserve."

- The Times Literary

Supplement cepts and quantitative methods of the new history, bringing the best of economics, sociology, political science, archaeology, and demography into historical research.

Four times a year $J I H$ brings you original articles and reviews that explore a variety of topics without limit to geographical area or chronological order. Select recent and forthcoming articles:

Meeting Needs and Suppressing Desires: Consumer Cboice Models and Historical Data Anne McCants

Russian Social History: A New Lease on Life? Don K. Rowney

The Political Foundations of Modern Economic Growth: England, 1540-1800 Gregory Clark

The Politics of Universal Health Insurance: Lessons from the Past? Theodore R. Marmor

1996 Rates Individual \$40; Institution \$125; Student (copy of current ID required) \& Retired $\$ 28$. Outside U.S.A add $\$ 16$ postage and handling. Canadians add additional $7 \%$ GST. Prepayment is required. Send checks drawn against a U.S. bank in U.S funds. AMEX, MC or VISA number to: The Journal of Interdisciplinary History 55 Hayward Street Cambridge, MA 02142 Tel: 617-253-2889 Fax:617-577-1545 journals-orders@micedu Published quarterly in summer, autumn. winter, and spring by The MIT Press. ISSN $0022-1953$ Prices subject to change without notice

Browse through MIT Press Journals catalog via the following URL: http://www-mitpress.mit.edu 


\section{Recent articles:}

Black Women's Labor Market Status: Occupational Segregation in the United States and Great Britain

\section{Mary C. King}

The W. Arthur Lewis Lecture: Future Sustainable Latin American Growth: A Need for Savings

\section{Albert Fishlow}

Labor Force Participation of Black and White Married Women: Evidence from Urban Labor Markets

\section{Augustin Kwasi Fosu}

High School Athletics and the Wages of Black Males

Bradley T. Ewing
Examines issues

related to the

economic status of

Black and Third

World peoples.

Identifies and

analyzes policy

prescriptions

designed to reduce

racial economic

inequality.
Dr. Thomas D. Boston EDITOR

Georgia Institute of Technology

\section{Published Quarterly}

\section{Subscription rates:}

Individuals: $\$ 52 / y r ; \$ 96 / 2 y r s ; \$ 128 / 3 y r s$

Institutions: $\$ 108 / \mathrm{yr} ; \$ 192 / 2$ yrs; $\$ 252 / 3 y r s$

Foreign surface mail add $\$ 32 / \mathrm{yr}$

Foreign airmail add $\$ 48 / \mathrm{yr}$

(Rates subject to change annually)

Visit us on the web at

http://WWW.TRANSACTIONPUB.COM

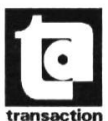

TRANSACTION PUELISHERS DEPARTMENT 2097

RUTGERS-THE STATE UNIVERSITY

NEW BRUNSWICK, NEW JERSEY 08903 